\title{
Comparative Chemical Composition and Antibacterial Activities of Myrtus communis L. Essential Oils Isolated from Tunisian and Algerian Population
}

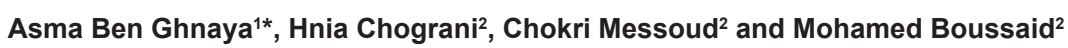

${ }^{1}$ Laboratory of Microorganisms and Active Biomolecules, Department of Biology, Faculty of Sciences of Tunis. Campus Universitaire, 2092 Tunis, Tunisia ${ }^{2}$ National Institute of Applied Sciences and Technologies (INSAT), Department of Biology, Laboratory of Plant Biotechnology, Centre Urbain Nord, BP 676, 1080 Tunis, Tunisia

\begin{abstract}
The chemical composition of Essential oils isolated by hydrodistillation from leaves of Tunisian and Algerian Myrtus communis L. population was analyzed by gas chromatography (GC) and gas chromatography/mass spectrometry (GC/MS). Twenty three compounds were identified, representing $93.73 \%$ of total oil, which was found to be rich in monoterpenes hydrocarbons (53.38\%) particularly a-Pinène (35.30\%) and $\alpha$-limonène (14.76\%). The physico-chemical properties were determined. The percentage of all components varied within and among population. The highest percentages of $\alpha$-Pinène $(45.4 \%)$ and 1.8 -Cineole $(35.7 \%)$ were observed in the Algerian population. The percentage of $\alpha$-limonène was significantly higher in the Tunisian population (18.16\%). The study of antibacterial activity revealed that $10 \mu$ of Myrtus communis L. essential oil significantly inhibited the growth of five tested bacteria especially Escherichia coli, Staphylococcus aureus, Bacillus subtilis, Salmonella sp., and Listeria sp.
\end{abstract}

Keywords: Myrtus communis L; Myrtacea; Essential oils; Hydrodistillation; a-Pinène; 1.8-Cineole; Antibacterial activity

\section{Introduction}

Essential oils are volatile organic compounds found in various plant tissues such as fruits, leaves, flowers, bark, stem, seeds, wood and roots. The quality of essential oils depends on the several factors including the part of the plant used, the plant variety and its country of origin, the method of extraction and the refining process [1]. The volatile oil isolated from aromatic plants provides a number of ecological advantages to the plant. For example, they provide protection against predators and other enemies, and mediate plant-plant interactions including allelopathy $[2,3]$. Until recently, essential oils have been studied mostly from their flavor and fragrance viewpoints only for flavoring foods, drinks and other goods [4]. Actually, however, essential oils and their components are gaining increasing interest because of their relatively safe status, their wide acceptance by consumers and their exploitation for potential multi-purpose functional use [5]. Specially, Myrtle (Myrtus communis L.) is an evergreen shrub belonging to the family of Myrtaceae that grows spontaneously throughout the Mediterranean area. In Italy it grows along the coast and in the inner hills, and it is spread especially in the islands, where it is one of the most characteristic species. Myrtus communis L. is an annual plant that has been used since ancient times for medicinal, food and spices purposes. The leaves contain tannins, flavonoids such as quercetin, catechin and myricetin derivatives and volatile oils [6,7]. The fruits of this plant are mostly composed of volatile oils, tannins, sugars, flavonoids and organic acids such as citric and malic acids $[6,8]$. In past times, ripe fruits were used as food integrators because of their high vitamin contents. The fruit decoction was used to bathe new-borns with reddened skin, while the decoction of leaves and fruits was useful for sore washing. The decoction of the leaves is still used for vaginal lavage, enemas and against respiratory diseases $[9,10]$. The essential oil obtained from the leaves by steam distillation is also important in perfumery [6]. Besides, the M. communis L. essential oil obtained from the leaves was used in the past for the treatment of lung disorders [11]. The essential oil obtained from this species has been widely investigated. Its composition is quite variable [12-14]. One of the main constituents of myrtle essential oil is 1,8-cineole [15]. The isolation of essential oils from Myrtus communis leaves is usually obtained by hydrodistillation method with a Clevenger-type apparatus, according to the Italian Official Pharmacopoeia. The chemical composition of the essential oils, analysed by Gas/Cromatography (G/C), generally exhibits $\alpha$-pinene, $11 \%$; 1,8-cineole, 16\%; linalool, $12 \%$; $\alpha$-terpineol, $7 \%$; and limonene, $5 \%$ [16]. The oil composition is highly influenced by the geographic origin of the plant $[17,18]$. According to the numerous published papers on the topic, myrtle essential oil possesses strong antimicrobial activity that makes it a valuable raw material for the cosmetic, pharmaceutical and foodstuff industries [19,20]. Earlier studies showed the antimicrobial properties of Myrtus essential oil against several clinical strains and in particular against Helicobacter pylori [21]. Moreover, Romani et al. [22] showed the biological activities of tannins, including anticancer and antioxidant. Other, studies have indicated that myrtle plant could be used as a source of antioxidant and antibacterial activities [23]. Generally, these studies were mainly focused towards the phenolic compounds in myrtle extracts [17].

Thus, essential oils are gaining remarkable interest for their potential multipurpose use as antioxidant, antibacterial, and antiseptic agent $[24,25]$.

The present work therefore, attempts to determine the chemical composition and evaluate antibacterial activity of essential oil isolated from leaves of Tunisian and Algerian Myrtus communis L. population. So, we assessed the antibacterial activity of the essential oils against five tested bacteria.

*Corresponding author: Asma Ben Ghnaya, Laboratory of Microorganisms and Active Biomolecules, Department of Biology, Faculty of Sciences of Tunis. Campus Universitaire, 2092 Tunis, Tunisia, Tel: 0021623334 084; E-mail: benghnaya_asma@yahoo.fr

Received June 18, 2013; Accepted July 06, 2013; Published July 10, 2013

Citation: Ghnaya AB, Chograni H, Messoud C, Boussaid M (2013) Comparative Chemical Composition and Antibacterial Activities of Myrtus communis L. Essential Oils Isolated from Tunisian and Algerian Population. J Plant Pathol Microb 4: 186 doi:10.4172/2157-7471.1000186

Copyright: @ 2013 Ghnaya AB, et al. This is an open-access article distributed under the terms of the Creative Commons Attribution License, which permits unrestricted use, distribution, and reproduction in any medium, provided the original author and source are credited. 


\section{Materials and Methods}

\section{Plant material}

Samples of Myrtus communis L., were collected at random from Tunisian and Algerian population. Ten individuals for each population were used for the analysis of their essential oil. Because the species multiplies through both sexual and vegetative reproduction, samples were collected at a distance of $>20 \mathrm{~m}$ apart to avoid sampling from the same parent. Vouchers specimens are deposited in the herbarium of the National Institute of Applied Science and Technology.

\section{Isolation of the essential oils}

The essential oils were extracted by hydrodistillation of fresh plant material using a Clevenger-type apparatus. For each sample, the oil was isolated from $20 \mathrm{~g}$ of fresh leaves, which had been ground in liquid nitrogen. The powder obtained was macerated in $200 \mathrm{ml} \mathrm{n}$-hexane for $12 \mathrm{~h}$. After filtration, the essential oil was dried using a rotary evaporator $\left(60^{\circ} \mathrm{C}\right)$. The yield represents $0.5 \%$ of the fresh sample weight. The oils were stored at $4^{\circ} \mathrm{C}$ in the dark until analysis.

\section{Analysis of the essential oils}

Oils were analyzed using an Agilent 6980 series gas chromatograph, equipped with a flame ionization detector (FID, $280^{\circ} \mathrm{C}$ ) and a splitsplitless injector $\left(220^{\circ} \mathrm{C}\right)$ attached to an HP INNOWAX column $(30 \mathrm{~m}$, $0.25 \mathrm{~mm} ; 0.25 \mu \mathrm{m}$ film thickness). Helium (He) was used as the carrier gas at a flow rate of $2 \mathrm{ml} / \mathrm{min}$. Temperature was programmed to range from 50 to $220^{\circ} \mathrm{C}$ at $8^{\circ} \mathrm{C} / \mathrm{min}$ and the final temperature was held for 10 min. A $2 \mu \mathrm{l}$ aliquot of sample, diluted in $10 \mathrm{ml}$-hexane, was injected. GC-MS analysis was performed on an HP 5890 series II instrument under the following conditions: injection of $2 \mu \mathrm{l}$ of sample; HP-5MS capillary column $(30 \mathrm{~m} \times 0.25 \mathrm{~mm}$; coating thickness, $0.25 \mu \mathrm{m})$; oven temperature programmed to range from 50 to $240^{\circ} \mathrm{C}$ at a rate of $5^{\circ} \mathrm{C} /$ min; carrier gas, He; flow rate, $1.2 \mathrm{ml} / \mathrm{min}$; split ratio, 1:60; ionization energy, $70 \mathrm{eV}$; scan time, $1 \mathrm{~s}$; mass range from 40 to $300 \mathrm{~m} / \mathrm{z}$. The mass spectrometer was a HP 5972 and the total electronic impact mode at 70 $\mathrm{eV}$ was used.

\section{Physicochemical properties of essential oil}

The essential oil components for each individual were identified through retention indices, determined by standards injected under the same chromatographic conditions. In addition, the compounds were also identified by comparison of their retention indices with those reported in the literature and by comparison of their mass spectra with the HP chemstation database HP NBS $75 \mathrm{~K}$. L. Percentages of compounds were determined from their GC peak areas. Injections were repeated twice for each sample.

\section{Antibacterial activity}

Microbial strains: The antimicrobial activity was tested using oils from each population against Escherichia coli ATCC10536, Staphylococcus aureus ATCC 6538, Bacillus subtilis ATCC 6633, Salmonella sp., and Listeria sp. Bacterial strains were cultured overnight at $37^{\circ} \mathrm{C}$ in nutrient broth (Scharlau Microbiology, Spain). For the antimicrobial tests, LB medium was used.

\section{Antibacterial activity assays}

The antimicrobial activity of oils was determined through the agar disc diffusion and the broth dilution methods. The minimum inhibitory concentration (MIC) and the minimum bactericidal concentration (MBC) were determinated. All tests were performed in duplicate.
Disc diffusion method: The disc diffusion method was made according to Sacchetti et al. [26]. Triptic soy agar (TSA) was distributed into sterilized Petri dishes with a diameter of $9 \mathrm{~cm}(15 \mathrm{ml})$. One hundred microliters of suspension of the tested microorganisms, containing $5 \times 10^{5} \mathrm{CFU} / \mathrm{ml}$ of bacterial strains was poured in TSA. The filter paper discs ( $6 \mathrm{~mm}$ in diameter) were individually impregnated with $10 \mu \mathrm{l}$ of each oil and then placed onto the agar plates. Before incubation, all Petri dishes were kept in the refrigerator $\left(4^{\circ} \mathrm{C}\right)$ for $2 \mathrm{~h}$ and incubated after at $37^{\circ} \mathrm{C}$ for $24 \mathrm{~h}$ for bacteria growth. After incubation, the diameters $(\mathrm{mm})$ of the inhibition zones were measured including the diameter of discs. The antimicrobial potentials were estimated according to indices reported by Rodriguez Vaquero et al. [27]. Gentamycin $(30 \mu \mathrm{g} / \mathrm{disc})$ and DMSO served as a positive and negative control

Determination of minimum inhibitory (MIC) and bactericidal (MBC) concentrations: Serial dilutions of $1 / 10,1 / 20$ and $1 / 30$ were made with dimethylsulphoxide (DMSO) and $10 \mu \mathrm{l}$ of each dilution were put down on sterile paper discs (6 $\mathrm{mm}$ diameter) placed on the surface of inoculated Petri dishes. The MIC was defined as the lowest concentration of the total essential oil at which the microorganism does not demonstrate visible growth [28]. Referring to results of the MIC assay, the minimum bactericidal concentration (MBC) was determined. Fifty microliters from each dilution of essential oil, showing growth inhibition zone in disc diffusion method, were added to $5 \mathrm{ml}$ of TSA broth tubes then incubated at $37^{\circ} \mathrm{C}$ for $24 \mathrm{~h}$ in an incubator shaker. From tubes without microbial growth, $0.1 \mathrm{ml}$ of cells was spread on TSA agar plates. MBCs were determined as the highest dilution at which no growth occurred on the plates.

\section{Statistical analysis}

For each sample from each locality, we calculated the mean percentage of compounds established on the three samples. The variations of oils among populations and of their biological activities were tested by a variance analysis at $p<0.001$ and $p<0.05$ [29]. The significance of differences between means was determined by Duncan's multiple range test (DMRT) at $\mathrm{p}<0.05$.

\section{Results}

\section{Chemical composition of Myrtus communis L. essential oil}

Essential oil obtained by hydrodistillation of fresh leaves of Myrtus communis L. had a light yellow color and a pungent odor. The chromatographic analysis showed a complex mixture of components with a consistent fraction of monoterpenes and sesquiterpenes. The list of the compounds, in order of elution, and the quantitative data, are reported in Table 1 . Twenty three oil compounds were identified accounting for $93.73 \%$ of total oil, while $6.27 \%$ of the oil remained unidentified. The monoterpenes hydrocarbons displayed the highest contribution (53.38\%) among which $\alpha$-Pinène (35.30\%) and $a$-limonène (14.76\%) were the most abundant. Whereas, the oxygenated monoterpenes represented only $34.31 \%$ of the total oil. In comparison with monoterpenes, the esters were relatively weak with $4.31 \%$. The sesquiterpene were the poorest fraction (1.73\%). The percentage of all components varied within and among population (Table 1). The highest percentages of $\alpha$-Pinène (45.4\%) and 1.8-cineole (35.7\%) were observed in the Algerian population, respectively. The percentage of a-limonène was significantly higher in the Tunisian population (White Ballouta "WB": 18.16\%)

\section{Antibacterial activity assays}

The in vitro antimicrobial activity of the essential oils estimated by 
Citation: Ghnaya AB, Chograni H, Messoud C, Boussaid M (2013) Comparative Chemical Composition and Antibacterial Activities of Myrtus communis L. Essential Oils Isolated from Tunisian and Algerian Population. J Plant Pathol Microb 4: 186 doi:10.4172/2157-7471.1000186

Page 3 of 5

\begin{tabular}{|c|c|c|c|c|c|}
\hline \multirow[t]{2}{*}{ Compound } & \multirow[t]{2}{*}{ RI } & \multicolumn{3}{|c|}{ Populations } & \multirow{2}{*}{$\begin{array}{c}\mathbf{P} \% \\
\text { (Over all population) }\end{array}$} \\
\hline & & Algerian population & Tunisian population (BB) & Tunisian population (WB) & \\
\hline$\alpha$-Thujene & 931 & $0.32 e$ & $0.27 f$ & $0.21 f$ & 0.26 \\
\hline a-Pinene & 938 & $45.4 a$ & $30.50 \mathrm{a}$ & $30.00 \mathrm{a}$ & 35.30 \\
\hline$\beta$-Pinene & 978 & $0.22 f$ & $0.32 f$ & $0.48 f$ & 0.34 \\
\hline a-Phellandrene & 1006 & $0.11 f$ & $0.22 f$ & $0.23 f$ & 0.18 \\
\hline 3-Carene & 1008 & $0.18 f$ & $0.29 f$ & $0.34 f$ & 0.27 \\
\hline 2-Carene & 1012 & $0.85 \mathrm{e}$ & $1.50 \mathrm{e}$ & $0.83 f$ & 1.06 \\
\hline$\rho$-Cymene & 1026 & $0.48 \mathrm{e}$ & $0.95 \mathrm{e}$ & $0.55 f$ & 0.66 \\
\hline a-Limonene & 1031 & $8.36 c$ & $17.78 \mathrm{~b}$ & $18.16 \mathrm{~b}$ & 14.76 \\
\hline 1-8-cinéole & 1040 & $35.7 b$ & $20.90 b$ & $22.30 \mathrm{~b}$ & 26.30 \\
\hline$\beta$-Ocimene & 1050 & $0.38 \mathrm{e}$ & $3.40 \mathrm{~d}$ & $3.18 d$ & 2.32 \\
\hline a-Terpinolene & 1088 & $0.45 \mathrm{e}$ & 0.41 & $0.41 \mathrm{f}$ & 0.42 \\
\hline$\beta$-linalool & 1105 & $1.93 d$ & $10.1 \mathrm{c}$ & $9.24 \mathrm{c}$ & 7.09 \\
\hline Trans-Pinocarveol & 1161 & $0.15 f$ & $0.29 \mathrm{e}$ & $0.23 f$ & 0.22 \\
\hline Terpinen-4-ol & 1177 & $0.35 \mathrm{e}$ & $0.29 \mathrm{e}$ & $0.27 f$ & 0.30 \\
\hline Myrtenyl acétate & 1335 & $0.13 f$ & $0.84 \mathrm{e}$ & $0.89 f$ & 0.62 \\
\hline$\beta$-caryophylléne & 1418 & $0.34 \mathrm{e}$ & $0.39 \mathrm{e}$ & $0.37 f$ & 0.36 \\
\hline a-Humulene & 1454 & $0.30 \mathrm{e}$ & $1.30 \mathrm{e}$ & $1.17 \mathrm{e}$ & 0.92 \\
\hline$\beta$-caryophyllene epoxide & 1534 & $0.71 \mathrm{e}$ & $0.34 f$ & $0.42 f$ & 0.49 \\
\hline Caryophyllene oxide & 1581 & $0.22 f$ & $0.50 f$ & $0.63 f$ & 0.45 \\
\hline a-Caryophyllene & 1600 & $0.11 \mathrm{f}$ & $\operatorname{tr}$ & $\operatorname{tr}$ & 0.03 \\
\hline$\beta$-fenchyl alcohol & 1633 & $0.46 \mathrm{e}$ & $\operatorname{tr}$ & $\operatorname{tr}$ & 0.15 \\
\hline a-Amorphene & 2018 & $0.12 f$ & $\operatorname{tr}$ & $\operatorname{tr}$ & 0.04 \\
\hline Hydroquinone & 2032 & $0.44 \mathrm{e}$ & $1.58 \mathrm{e}$ & 1.41 & 1.14 \\
\hline Total identified (\%) & & 97.71 & 92.17 & 91.32 & 93.73 \\
\hline Oil yield & & 0.54 & 0.48 & 0.50 & 0.50 \\
\hline
\end{tabular}

Table 1: Chemical composition of Myrtus communis L. essential oils isolated from Algerian and Tunisian population: (Black Ballouta: BB and White Ballouta: WB).

\begin{tabular}{|c|c|c|c|c|c|c|c|c|c|c|c|c|c|}
\hline \multirow[t]{4}{*}{ Bacteria } & \multirow[t]{4}{*}{ Source no. } & \multicolumn{12}{|c|}{ Inhibition zone (mm) } \\
\hline & & \multicolumn{12}{|c|}{ Populations } \\
\hline & & \multicolumn{4}{|c|}{ Algerian population } & \multicolumn{4}{|c|}{ Tunisian population (BB) } & \multicolumn{4}{|c|}{ Tunisian population (WB) } \\
\hline & & $\mathrm{C} 1$ & $\mathrm{C} 2$ & C3 & $\mathrm{C} 4$ & $\mathrm{C} 1$ & $\mathrm{C} 2$ & $\mathrm{C} 3$ & $\mathrm{C} 4$ & $\mathrm{C} 1$ & $\mathrm{C} 2$ & C3 & $\mathrm{C} 4$ \\
\hline \multicolumn{14}{|l|}{ Gram-negative } \\
\hline Escherichia Coli & ATCC10536 & $15 b$ & $8 c$ & $8 c$ & $8 c$ & $20 a$ & $8 c$ & 7c & NA & $15 b$ & $9 c$ & $10 c$ & $8 c$ \\
\hline Salmonella & - & $14 b$ & $7 c$ & $7 c$ & $6 c$ & $12 b$ & $8 c$ & $6 c$ & $6 c$ & $11 \mathrm{c}$ & $6 c$ & $9 c$ & $12 b$ \\
\hline \multicolumn{14}{|l|}{ Gram-positive } \\
\hline Staphylococcus aureus & ATCC 6538 & $10 c$ & $7 c$ & $7 c$ & $8 c$ & $23 a$ & $22 a$ & $8 c$ & $1 d$ & $21 a$ & $19 a$ & $8 c$ & $8 c$ \\
\hline Bacillus subtilis & ATCC 6633 & $9 c$ & $8 c$ & $8 c$ & $8 c c$ & $12 b$ & $9 c$ & $7 c$ & $6 c$ & $10 \mathrm{c}$ & $8 c$ & $8 c$ & $7 \mathrm{c}$ \\
\hline Listéria & - & $10 c$ & $7 c$ & $7 c$ & $7 c$ & $15 b$ & $8 c$ & $7 c$ & $7 c$ & $7 c$ & $9 c$ & NA & $8 c$ \\
\hline
\end{tabular}

Where $\mathrm{C} 1: 10 \mu \mathrm{l}$ of essential oil and C2: 1/10, C3: 1/20, C4: $1 / 30$.

Values followed by the same letter under the same line are not significantly different (Duncan's multiple range test at $\mathrm{P}>0.05$ ).

Table 2: Antibacterial activity estimated by diameter of inhibition of Myrtus communis L. essential oils isolated from Algerian and Tunisian population: (Black Ballouta: BB and White Ballouta: WB).

the diameter of inhibition varied according to populations and bacteria strains (Table 2). The highest activity was observed against E. coli ATCC10536 with strongest inhibition zones $(15 \mathrm{~mm})$ recorded for the essential oils isolated from Algerian population of Myrtus communis L.

However, for the essential oils isolated from Tunisian population (Black and White Ballouta: "BB" and "WB") of Myrtus communis L., the highest activity was observed against Staphylococcus aureus ATCC 6538 with strongest inhibition zones ( 23 and $21 \mathrm{~mm}$ respectively) the variety: WB). Also our results showed a significant inhibition of antimicrobial activity with the dilution of the essential oil for the tunisian and algerian population (Table 2).

\section{Discussion}

The essential oil of Myrtus communis L. was previously investigated. In agreement with our result, most studies indicated that $\alpha$-Pinene and 1,8 -Cineole $(35.30 \%$ and $26.30 \%$ respectively) were the major components of the Myrtus communis L. oil [30-35]. Nervertheless, in our study, the percentage of all components varied within and among population (Table 1). The highest percentages of $\alpha$-Pinène $(45.4 \%)$ and 1.8 -cineole $(35.7 \%)$ were observed in the Algerian population. The percentage of $\alpha$-limonène was significantly higher in the Tunisian population (18.16\%). This significant difference in the chemical composition of the extracted oil according to populations may be due to one of the following reasons:

- Nutrients of different soils and their accumulation in the leaves may result in different metabolism and production of different bioproducts and volatile oils,

- The change in genes through generations and hybridizations, naturally and induced, may result in production of a variety of volatile 
oils compared to nectars or those of different habitat, the out-crossing species breeding system would have to play a major role in this genetic diversity $[30,36]$.

- Acclimation of species to the environment in which it was grown in the past,

\section{- Differences may be due to different ecotypes of the species.}

These differences could be related to the environmental factors (climate, season and soils), the genetic diversity of the species, the geographic conditions, the harvest period and the isolation technique [37]. These factors influenced the available resources, the plant's biosynthetic pathways, the metabolism and consequently the relative proportion of the main characteristic compounds, their nature and their production. This leads to the existence of different origin, as well as seasonal variation throughout the plant's vegetative cycle [38]. Also, it is likely that the observed heterogeneities between populations could correspond to particular adaptive selection pressure traits (climate, soil, etc.).

Subsequently, we study antibacterial activity of Myrtus communis L. essential oils isolated from Tunisian and Algerian population.

For the antibacterial activity, we revealed that this activity varied according to population and bacteria strains (Table 2). The highest activity was observed against E. coli ATCC10536 with strongest inhibition zones $(15 \mathrm{~mm}$ ) recorded for the essential oils isolated from Algerian population of Myrtus communis L. However, for the essential oils isolated from Tunisian population (Black and White Ballouta: "BB" and "WB") of Myrtus communis L., the highest activity was observed against Staphylococcus aureus ATCC 6538 with strongest inhibition zones (23 and $21 \mathrm{~mm}$ respectively) the variety: WB). The results presented in this study (Table 2) are in line with the small number of published papers on the effects on bacterial growth of Myrtus communis L. essential oils. Salvagnini et al. [39] reported the antimicrobial activity of essential oil from leaves of Myrtus communis L. against Staphylococcus aureus, S. epidermidis, E. coli, B. subtilis and Serratia marcescens. Yadegarinia et al. [20] have demonstrated the activity of Myrtus communis L. essential oil against E. coli, S. aureus and Candida albicans.

Besides, the antibacterial effect of Myrtus communis L. essential oils have been recently reported by Akin et al. and Janetti et al. [4,11]. The antibacterial activity of Myrtle infusions was also previously investigated [40] and their effects are generally attributed to their major components.

Nevertheless, in this study, we will find reports for the first time of the Comparative chemical composition and antibacterial activity of Myrtus communis L. essential oils isolated from Tunisian and Algerian population.

Our study showed that the composition of Myrtus communis L. essential oil is rich in oxygenated monoterpenes, especially 1,8-Cineole and $\alpha$-Pinene which are known to possess a significant antibacterial activity [11]. However, it is difficult to compare the data with the literature because several variables influence the results, such as the different chemical composition due to the environmental factors (such as geography, temperature, day length, nutrients, etc) of the plant [4]. Our study on Tunisian and Algerian essential oil of Myrtus communis L. obtained by hydrodistillation demonstrates a high variation in the composition of oils and their biological activity potentials according to populations. This points out the importance of the genetically and morphologically characterization of varieties within the species and of populations within varieties wherever, antimicrobial activity of oils were determined. Algerian populations were chemically distinct and showed oils rich in $\alpha$-Pinène (45.4\%) and 1.8-cineole ((35.7\%).

Based on our preliminary results, the essential oils of Myrtus communis L. could be for various commodities of medicinal and pharmacological attributes. Besides, the ease of cultivation and rapid growth of Myrtus communis L. makes it, potentially, a very valuable natural resource for the commercial production of pharmaceuticals, over and above the present production of Myrtle oil for medicinal purposes. It is likely, that in the years ahead Myrtus communis L. metabolites other than volatile constituents will form part of the armory drugs available to the physician for the treatment or prevention of human diseases.

\section{References}

1. Dicker GJ, Nicholas PV (1976) Essential oils. Gas Chromatography in Food Analysis 192.

2. Batish DR, Singh HP, Kohli RK, Kaur S (2008) Eucalyptus essential oil as a natural pesticide. Forest Ecol Manag 256: 2166-2174.

3. Singh HP, Kaur S, Mittal S, Batish DR, Kohli RK (2008) Phytotoxicity of major constituents of the volatile oil from leaves of Artemisia scoparia Waldst. \& Kit. Z Naturforsch C 63: 663-666.

4. Akin M, Aktumsek A, Nostro A (2010) Antibacterial activity and composition of the essential oils of Eucalyptus camaldulensis Dehn and Myrtus communis L. growing in Northern Cyprus. African Journal of Biotechnology 9: 531-535.

5. Ormancey X, Sisalli S, Coutiere $P$ (2001) Formulation of essential oils in functional perfumery. Parfums, Cosmetiques, Actualites 157: 30-40.

6. Baytop T (1999) Therapy with medicinal plants in Turkey (Past and Present) Nobel Tip Kitapevleri Press, Istanbul.

7. Romani A, Pinelli P, Mulinacci N, Vincieri FF, Tattini M (1999) Identification and quantitation of polyphenols in leaves of Myrtus communis L. Chromatographia 49: $17-20$

8. Martin T, Rubio B, Villaescua L, Fernandez L, Diaz AM (1999) Polyphenolic compounds from pericarps of Myrtus communis. Pharm Biol 37: 28-31.

9. Maccioni S, Tomei PE, Rizzo A (1995) The medicinal use dele wild and cultivated plant species in the folk tradition of the Val di Magra. Memoirs of the Academy of Sciences Lunigianese 389-435

10. Marcini G, Maccioni S (1998) Riviera in a nutshell. The lower Val di Magra Genova: Sagep.

11. Zanetti S, Cannas S, Molicotti P, Bua A, Cubeddu M, et al. (2010) Evaluation of the Antimicrobial Properties of the Essential Oil of Myrtus communis L. against Clinical Strains of Mycobacterium spp. Interdiscip Perspect Infect Dis 2010.

12. Lawrence BM (1990) Progress in essential oils. Myrtle oil. Perfumer and Flavorist 15: 65- 66.

13. Lawrence BM (1993) Progress in essential oils. Myrtle oil. Perfumer and Flavorist 18: 52-55.

14. Lawrence BM (1996) Progress in essential oils. Myrtle oil. Perfumer and Flavorist 21: 57-58.

15. Bradesi TP, Casanova J, Costa J, Bernardini AF (1997) Chemical composition of myrtle leaf oil from Corsica (France). Journal of Essential Oil Research 9: 283-288.

16. Ozek T, Demirci B, Baser KHC (2000) Chemical composition of Turkish myrtle oil. J Essential Oil Res 12: 541-544

17. Chryssavgi G, Vassiliki P, Athanasios M, Kibouris T, Komaitis M (2008) Essentia oil composition of Pistacia lentiscus and Myrtus communis L: Evaluation of antioxidant capacity of methanolic extracts. Food Chem 107: 1120-1130.

18. Boelens M, Jimenez R (1992) The Chemical Composition of Spanish Myrtle Oils. Part II. J Essent Oil Res 4: 349-353.

19. Bouzouita N, Kachouri F, Hamdi M, Chaabouni M (2003) Antimicrobial activity of essential oils from Tunisian aromatic plants. Flavour Frag J 18: 380-383.

20. Yadegarinia D, Gachkar L, Rezaei MB, Taghizadeh M, Astaneh SA, et al. (2006) 
Citation: Ghnaya AB, Chograni H, Messoud C, Boussaid M (2013) Comparative Chemical Composition and Antibacterial Activities of Myrtus communis L. Essential Oils Isolated from Tunisian and Algerian Population. J Plant Pathol Microb 4: 186 doi:10.4172/2157-7471.1000186

Biochemical activities of Iranian Mentha piperita L. and Myrtus communis L. essential oils. Phytochemistry 67: 1249-1255.

21. Deriu A, Branca G, Molicotti P, Pintore G, Chessa M, et al. (2007) In vitro activity of essential oil of Myrtus communis L. against Helicobacter pylori. Int $J$ Antimicrob Agents 30: 562-563.

22. Romani A, Coinu R, Carta S, Pinelli P, Galardi C, et al. (2004) Evaluation of antioxidant effect of different extracts of Myrtus communis L. Free Radic Res 38: 97-103.

23. Hayder N, Abdelwahed A, Kilani S, Ammar RB, Mahmoud A, et al. (2004) Antigenotoxic and free-radical scavenging activities of extracts from (Tunisian) Myrtus communis. Mutat Res 564: 89-95.

24. Alem G, Mekonnen Y, Tiruneh M, Mulu A (2008) In vitro antibacterial activity of crude preparation of myrtle (Myrtus communis) on common human pathogens. Ethiop Med J 46: 63-69.

25. Gündüz GT, Gönül SA, Karapinar M (2009) Efficacy of myrtle oil against Salmonella Typhimurium on fresh produce. Int J Food Microbiol 130: 147-150.

26. Sacchetti G, Maietti S, Muzzoli M, Scaglianti M, Manfredini S, et al. (2005) Comparative evaluation of 11 essential oils of different origin as functiona antioxidants, antibacterials and antimicrobials in foods. Food Chemistry 91 621-632.

27. Rodriguez Vaquero MJ, Alberto MR, Manca de Nadra MC (2007) Antibacteria effect of phenolic compounds from different wines. Food Control 18: 93-101.

28. Okeke MI, Iroegbu CU, Eze EN, Okoli AS, Esimone CO (2001) Evaluation of extracts of the root of Landolphia owerrience for antibacterial activity. J Ethnopharmacol 78: 119-127.

29. SAS (1990) SAS User's Guide: SAS STAT, SAS BASIC. Version 6, (4thedn), SAS Institute Inc., SAS Incl, Box 8000, Cary, NC 27512-8000, Cary, NC.

30. Messaoud C, Zaouali Y, Ben Salah A, Khoudja ML, Boussaid M (2005) Myrtus communis in Tunisia: variability of the essential oil composition in natural populations. Flavour Fragrance J 20: 577-582.
31. Mimica-Dukić N, Bugarin D, Grbović S, Mitić-Culafić D, Vuković-Gacić B, et al. (2010) Essential oil of Myrtus communis L. as a potential antioxidant and antimutagenic agents. Molecules 15: 2759-2770.

32. Ghannadi A, Dezfuly N (2011) Essential oil Analysis of Leaves of Persian True Myrtle. Int J Med Arom Plants 1: 48-50.

33. Derwiche E, Benziane Z, Chabir R, TaouilL R (2011) Characterisation of Volatiles and Evaluation of Antioxidant activity of the Flower Essential oils of Myrtus communis L. From Morocco. International Journal of Current Pharmaceutical Research 3: 17-23.

34. Messaoud C, Béjaoui A, Boussaid M (2011) Fruit color, chemical and genetic diversity and structure of Myrtus communis L. var. italica Mill. morph populations. Biochemical Systematics and Ecology 39: 570-580.

35. Brada M, Tabti N, Boutoumi H, Wathelet JP, Lognay G (2012) Composition of the essential oil of leaves and berries of Algerian myrtle (Myrtus communis L.) Journal of Essential Oil Research 24: 1-3.

36. Boussaïd M, Zaouali Y, Messaoud C, Ben Salah A, Ben Fadhel N (2002) Genetic diversity, mating system and essential oils in Rosmarinus officinalis L. Myrtus communis L. and Mentha pulegium L. 33rd International Symposium on Essential Oils, Portugal.

37. Abd El-Mageed AA, Osman AK, Tawfik AQ, Mohammed HA (2011) Chemica Composition of the Essential Oils of four Eucalyptus Species (Myrtaceae) from Egypt. Res J Phytochem 5: 115-122.

38. Flamini G, Cioni PL, Morelli I, Maccioni S, Baldini R (2004) Phytochemical typologies in some populations of M. communis L. on Caprione Promontory (East Liguria, Italy). Food Chem 85: 599-604.

39. Salvagnini LE, Oliveira JRS, Dos Santos LE, Moreira RR, Pietro RCLR (2008) Evaluation of the antibacterial activity of Myrtus communis (Myrtaceae) leaves. Revista Brasileira de Farmacognosia 18: 241-244.

40. Messaoud C, Laabidi A, Boussaid M (2012) Myrtus communis L. infusions: the effect of infusion time on phytochemical composition, antioxidant, and antimicrobial activities. J Food Sci 77: C941-C947. 